Lubbock for his investigations on the tides, and (2) Charles Lyell for his work, "Principles of Geology". The grounds for the latter award were announced as : (a) the comprehensive view taken of the subject, and its philosophical spirit and dignity; $(b)$ the important service rendered to science by specially directing the attention of geologists to effects produced by existing causes; (c) the author's admirable descriptions of many tertiary deposits ; $(d)$ the new mode of investigating tertiary deposits, which his labours have greatly contributed to introduce, namely, that of determining the relative proportions of extinct and still existing species, with the view of discovering the relative ages of distant and unconnected deposits. The Rumford medal was awarded to Prof. Macedonio Melloni, of Parma, for his researches and experiments on the diffusion of heat by radiation, and its relationship in lunar light. Melloni was director of the Meteorological Observatory, Mount Vesuvius, 1839-49, and became a foreign member of the Royal Society in 1839 ; he died in 1853.

\section{British Association: Norwich Meeting}

THE annual meeting of the British Association will be held next year in Norwich on September 4-11 under the presidency of Prof. W. W. Watts. The following sectional presidents have been appointed : Section A (Mathematical and Physical Sciences), Dr. F. W. Aston ; B (Chemistry), Prof. W. N. Haworth ; C (Geology), Prof. G. Hickling; D (Zoology), Prof. F. Balfour Browne; E (Geography), Prof. F. Debenham; F (Economic Science and Statistics), Prof. J. G. Smith; Gr (Engineering), Mr. J. S. Wilson; H (Anthropology), Dr. Cyril Fox; I (Physiology), Prof. P. T. Herring ; J (Psychology), Dr. Ll. Wynn Jones ; K (Botany), Mr. F. T. Brooks ; L (Educational Science), Dr. A. W. Pickard-Cambridge; M (Agriculture), Dr. J. A. Venn. The president of the Conference of Delegates of Corresponding Societies will be Prof. P. G. H. Boswell.

\section{Dud Dudley and the Coal-Iron Industry}

Throdar the publication of his little work "Mettallum Martis", 1665, Dud Dudley, 1599-1684, a son of Edward Sutton, Lord Dudley, has long enjoyed a reputation as being a pioneer in the use of coal, instead of charcoal, as a fuel for smelting iron. Most early writers on industrial history accepted Dudley's writings at their face value without inquiring into their correctness. A proposal made some years ago to erect a monument to him at Dudley, however, led to a closer scrutiny of what he had written and the state of the iron industry at the time, with the result that many of his assertions have been found impossible of belief, and many of his claims to our admiration as an outstanding pioneer have to be rejected. A review of the whole question was given by Mr. R. A. Mott on November 21 in a paper read to the Newcomen Society at the Iron and Steel Institute, and in the subsequent discussion Mr. Mott's views found general acceptance. Dudley lived in stirring times and had many adventures, but his work as an iron master was done when he was a young man. That he did make iron there seems no need to question, but that he produced good quality iron with the use of coal has to be rejected. Mr. Mott's view is that, as a historian, Dudley's veracity has to be questioned, while as a man he was an opportunist, vain and boastful. A consideration of the technical basis of his claims shows that they were impossible of achievement. The Trans. actions of the Newcomen Society contain several valuable papers on the history of the iron industry and these, with that of Mr. Mott, should be studied by all interested in this phase of industrial history.

\section{Cardiff Engineering Exhibition}

THe thirteenth annual exhibition at Cardiff, held under the auspices of the South Wales Institute of Engineers, opened on November 21 and closes on December 1. The main object of these exhibitions is educational and also to eneourage industry by bring. ing the manufacturers of machinery and plant into touch with the users. Whilst mining appliances were well represented, almost every branch of engineering activity has received attention. An outstanding feature of this year's display was an exhibition coal mine, equipped by the Coal Face Machinery Exhibitors' Association-an association which comprises nearly all the manufacturers of coal face machinery in Great Britain. It was installed not as an advertisement of any particular plant, but to show the possibilities of mechanisation at the coal face, and to keep mining engineers and others interested and informed of the most recent developments in this respect. The mine consists of a main roadway, a machine-mined heading and a longwall face, in which are placed examples of coal face machinery-longwall coal cutters and shearing machines, jigger and belt conveyors, dust filters and pneumatic drills. In the roadways and face, modern methods of supporting roof and sides are shown. The Department of Scientific and Industrial Research had a valuable exhibit illustrating some of the research activities of the National Physical Laboratory, the Fuel Research Station, the Chemical Research Laboratory and other scientific bodies. Thus, fatigue of metals, lubrication research, electric welding, alignment of machine tools, steel casting, microstructure of metals, corrosion of metals, hydrogenation of coal, smokeless fuel and industrial applications of X-ray analysis, were among the topics illustrated. An interesting exhibit consisted of turned objects made of some of the latest plastic materials derived from coal, and intended to display the artistic possibilities of such materials.

\section{Competitive Trials of British Military Aircraft}

THE periodical trials for the selection of new types of aircraft for R.A.F. equipment, now in progress, include some machines that have considerable technical interest. Two of the day and night fighters now being tested are monoplanes, designed and built by Messrs. Bristol and Vickers respectively. The British Service requirements for a fighter have hitherto put extreme manœuvrability in action first 